Papanikolas, N., T. G. Hadjikyriakou, M. Sebastianelli, and A. N. G. Kirschel. 2021. Habitat selection and interspecific competition between Sylvia warblers in Cyprus following the rapid expansion of a recent colonizer. Avian Conservation and Ecology 16(2):11. https://doi.org/10.5751/ ACE-01937-160211

Copyright (C) 2021 by the author(s). Published here under license by the Resilience Alliance.

Research Paper

\title{
Habitat selection and interspecific competition between Sylvia warblers in Cyprus following the rapid expansion of a recent colonizer
}

\author{
Nikolas Papanikolas $^{1}$ (D) , Thomas G. Hadjikyriakou ${ }^{1,2}$ (D) , Matteo Sebastianelli ${ }^{1}$ (D) and Alexander N. G. Kirschel ${ }^{1}$ \\ ${ }^{1}$ Department of Biological Sciences, University of Cyprus, Nicosia, Cyprus, ${ }^{2}$ Akrotiri Environmental Education Centre, Akrotiri, \\ Cyprus
}

ABSTRACT. Many island endemics around the world have evolved from populations of colonists. Further colonizations may lead to interactions between older and newer colonists. Little is known, however, regarding the impact of more recent island colonizers on incumbent congeners, partly because of a dearth of examples of natural colonizations in the recent past. Sardinian Warbler (Sylvia melanocephala) recently colonized Cyprus and has rapidly expanded its breeding range. We examined the impact of the Sardinian Warbler colonization on the endemic Cyprus Warbler ( $S$. melanothorax) and on another congener, the Spectacled Warbler $(S$. conspicillata). We performed 402 population surveys in 32 sample plots across the island, covering five different habitat types and variation across three seasons. Our results show that Cyprus Warbler has undergone a significant decline during the five years of the study, especially in disturbed habitats, while Sardinian and Spectacled Warbler populations have remained stable. Although the longer established Spectacled Warbler clearly segregated habitat with Cyprus Warbler, Sardinian Warbler numbers were negatively associated with Cyprus Warbler abundance, suggesting its presence may contribute to the endemic's decline. Maquis scrub was favored by both Cyprus Warbler and Sardinian Warbler, but the latter also occurred in high densities in disturbed habitats. The colonizer's prevalence in disturbed, mixed habitat, suggests it may replace the endemic in parts of its former range following anthropogenic perturbations. Natural colonizations may contribute to rapid population declines in island endemics in a similar way to introduced species, especially when combined with strong effects of habitat disturbance.

\section{Sélection de l'habitat et compétition interspécifique entre les fauvettes des jardins à Chypre à la suite de l'expansion rapide d'une espèce colonisatrice récente}

RÉSUMÉ. De nombreuses espèces endémiques des îles du monde entier ont évolué à partir de populations colonisatrices. De nouvelles colonisations peuvent ensuite donner lieu à des interactions entre les populations récentes et plus anciennes. On en sait peu, en revanche, au sujet de l'impact des colonisateurs les plus récents des îles sur leurs congénères déjà présents, en partie en raison de la rareté des exemples de colonisations naturelles dans un passé récent. La fauvette mélanocéphale (Sylvia melanocephala) a récemment colonisé Chypre et son territoire de reproduction s'est rapidement développé. Nous avons examiné l'impact de la colonisation de fauvettes mélanocéphales sur l'espèce endémique, la fauvette de Chypre ( $S$. melanothorax $)$ ainsi que sur un autre congénère, la fauvette à lunettes (S. conspicillata). Nous avons réalisé 402 enquêtes sur ces populations sur 32 territoires échantillons dans l'île, couvrant cinq types d'habitats et les variations au cours de trois saisons. Nos résultats indiquent que la fauvette de Chypre a connu un déclin important au cours des cinq dernières années de l'étude, en particulier dans les habitats perturbés, alors que les populations de fauvettes mélanocéphales et de fauvettes à lunettes sont restées stables. Même si la fauvette à lunettes, établie depuis plus longtemps, présente des habitats clairement séparés de ceux de la fauvette de Chypre, l'augmentation de la population de fauvettes mélanocéphales semble avoir coïncidé avec une baisse des nombres de fauvettes de Chypre, ce qui suggère que leur présence pourrait contribuer au déclin de l'espèce endémique. La fauvette de Chypre et la fauvette mélanocéphale semblent privilégier les broussailles et le maquis, mais cette dernière est également présente en forte densité dans les habitats perturbés. La prévalence des colonisateurs dans les habitats mixtes et perturbés suggère qu'ils pourraient remplacer l'espèce endémique dans certaines parties de son ancien territoire à la suite de perturbations anthropogéniques. Les colonisations naturelles pourraient contribuer au déclin rapide de certaines populations d'oiseaux endémiques des îles au même titre que les espèces introduites, en particulier lorsque ces phénomènes sont associés aux effets majeurs de la perturbation de l'habitat.

Key Words: habitat selection; invasive species; interspecific competition; island endemics; Mediterranean islands; Sylvia warblers

\section{INTRODUCTION}

Island endemism may result from populations colonizing islands that have adapted to the limited range of habitats found in their new environment, coupled with an absence of gene flow with mainland populations (Newton 2003). Additionally, a founder effect might result in phenotypic differences in island populations compared with mainland counterparts (Spurgin et al. 2014). As a result of their smaller population size and reduced genetic diversity, insular species are more vulnerable to extinction, because they may be unable to adapt to the threats posed by new

Correspondent author: Alexander N. G. Kirschel, Department of Biological Sciences,, University of Cyprus,, PO Box 20537,, Nicosia 1678,, Cyprus, kirschel@ucy.ac.cy 
colonizers (Ricklefs and Cox 1972) and habitat disturbance (Croonquist and Brooks 1993, Andrén 1994). Identifying the impact of new colonizers can be challenging because the timing of recent colonization events is seldom known. But, humans have often introduced species that have established populations in new regions around the world, and species introductions have been described as the second most frequent pressure on endemic species after habitat loss (Fahrig 2001, 2002, 2003, Bellard et al. 2016).

The impact of interactions with new colonizers is potentially greater on islands compared with continental regions (Blondel 2000), possibly because of the absence of coevolution between native insular species and potential competitors. Native insular species might be especially vulnerable to emerging competitive pressures. Such a negative impact of novel competitors is likely to be similar, regardless of if their origin is due to anthropogenic causes or natural colonization (Nackley et al. 2017). One factor that may contribute to the pressure on incumbent insular species is that islands rarely provide alternative habitats suitable for endemic species to shift their population ranges to in order to minimize competition with new colonizers (Jehl and Parkes 1983, Vilà and Hulme 2017).

A commonly cited example of such interspecific competition due to natural colonization of islands by mainland species is the case of Sylvia warblers in the Western Palearctic, where 17 Sylvia species regularly occur (Cramp and Brooks 1992). The outcomes of Sylvia warbler interactions vary, ranging from the displacement of native species by mainland colonizers to their coexistence (Cody and Walter 1976, Case and Cody 1987). Indeed, it has been argued that the ecological similarity of these Sylvia congeners has led to their segregation into different niches to reduce interspecific competition when they occur in sympatry (Cody 1978). On smaller islands, displacement of Sylvia warblers is hypothesized to have occurred, for example in Malta, where Spectacled Warbler $S$. conspicillata has declined over the last 30 years after a century of coexistence with the colonizing Sardinian Warbler (S. melanocephala; Shirihai et al. 2001). By contrast, eight Sylvia warbler species coexist along an ecological gradient in Catalonia (Guillaumet and Prodon 2011). The question of interspecific competition among Sylvia warblers thus remains controversial. Indeed, several studies have challenged the existence of competition among Mediterranean warblers proposed by Cody and Walter (1976), by arguing that warblers existing in the same habitat are segregated by their ecological preferences instead of by direct competition for space (Martin and Thibault 1996, Pons et al. 2008, Guillaumet and Prodon 2011)

In Cyprus, 11 Sylvia species regularly occur (Stylianou 2015). Of these, just three breed on the island: Cyprus Warbler $(S$. melanothorax), Sardinian Warbler, and Spectacled Warbler (Flint and Stewart 1992). These three species are phylogenetically related and belong to the Melizophilous sub-group, which includes Sylvia species confined to the Mediterranean region (Blondel et al. 1996, Voelker and Light 2011). The Cyprus Warbler is an endemic breeding species in Cyprus (Shirihai et al. 2001) whose population has strongly declined recently in western Cyprus, accompanied by a simultaneous increase in the breeding population of Sardinian Warbler (Pomeroy and Walsh 2000, 2002, Flint and McArthur 2014, Pomeroy et al. 2016). Previously a winter visitor, Sardinian Warbler established a breeding population in the early 1990s, on the Akamas Peninsula in the western part of the island (Frost 1994, Pomeroy and Walsh 2000).

Previous work in Cyprus has not found a direct causal explanation for the decrease of Cyprus Warbler numbers in areas colonized by Sardinian Warbler. Specifically, Jones (2006) found no evidence of competitive interactions during the breeding season in areas where the two species breed syntopically. Consistent with western Mediterranean Sylvia warbler communities (Martin and Thibault 1996), Cyprus and Sardinian Warblers appeared to establish home ranges independently of one another, with substantial home range overlap (Jones 2006). Also, Ieronymidou et al. (2012) argued against the case of competitive displacement of Cyprus warbler by Sardinian Warbler because, in areas where they coexisted, they exhibited subtly different preferences within similar habitat types. Ieronymidou et al. (2012) determined that both species' population trends are differentially affected by recent changes in land use, while Flint and McArthur (2014), in contrast, hypothesized that interspecific territoriality from Cyprus Warbler and interspecific aggression by Sardinian Warbler are two of the main factors driving the Cyprus Warbler decline. Subsequently, Hellicar and Kirschel (2021) found that both Cyprus warbler and Sardinian warbler occurred in lower numbers when the other occurred in high densities, preferring different goat and sheep grazing regimes. Spectacled Warbler favors the most arid parts of the island and has been described as resident on the island since at least the 19th century (Bucknill 1909). Despite it being one of the three Sylvia species breeding in Cyprus, its interactions with its two congeners, Cyprus and Sardinian warbler, have been overlooked by previous studies and its potential involvement in interspecific competition on the island is unknown.

In this study, our main objective was to unveil the possible impact of the recent establishment and expansion of a breeding population of Sardinian Warbler on the densities of its congeners, Cyprus and Spectacled Warblers, with much longer established breeding populations in Cyprus, in the light of previous work on competition and turnover of species on islands (Mayr 1965, Jehl and Parkes 1983, Dhondt 2012, Bellard et al. 2016, Hoffmann and Courchamp 2016, Wilson et al. 2016). Through this study we aimed to quantify population densities and dynamics in different areas, habitat types, and across seasons. In addition to the natural habitat types examined (pine forest, maquis, garrigue, and salt marsh) we included disturbed habitat mixtures, where severe anthropogenic disturbance has occurred (e.g., fragmentation, plantation of non-native plants, and agriculture) or wildlife severely disturbed the habitat, given that any of the study species might benefit from habitat disturbance (Cody and Walter 1976, Pomeroy and Walsh 2006, Ieronymidou et al. 2012, Hellicar and Kirschel 2021). Environmental factors that might affect species presence, such as altitude, temperature, and precipitation were also considered. Coexistence of congeners might result in strong interspecific interactions (Dhondt 2012, Grether et al. 2013), thus revealing how the presence of each species influences the densities of the other two species (Braz et al. 2020) and quantifying these effects was a major objective of the study.

\section{METHODS}

\section{Study species}

Cyprus Warbler is an endemic breeder in Cyprus and a partial migrant, with a significant part of its population wintering in 
Israel, Jordan, and in the Sinai Peninsula (Shirihai et al. 2001), with a population size estimate of 70,000-140,000 pairs (BirdLife International 2017). It has the most restricted breeding range among all Sylvia species (Shirihai et al. 2001). The Cyprus Warbler is included in Annex I of the EU Birds Directive 2009/147/EC, suggesting that special conservation measures need to be taken to ensure species survival and reproduction (European Parliament 2009). In addition, it is classified as SPEC 2 in BirdLife International's European birds of conservation concern (BirdLife International 2017). Cyprus Warbler is widespread in Cyprus and breeds in a variety of habitats, even though it prefers tall maquis (highest densities during breeding season and in winter) and garrigue (preferably those dominated by Cistus spp.; Cramp and Brooks 1992). It avoids open areas including cultivations, dense forests, and dry areas with an average annual rainfall of less than $340 \mathrm{~mm}$ (Flint and McArthur 2014). It occurs commonly in seminatural scrub habitats (Ieronymidou et al. 2012) and where there is a higher diversity of perennial plants (Hellicar and Kirschel 2021). Populations have been recorded from sea level up to an altitude of $1400 \mathrm{~m}$ a.s.l., becoming progressively less common in areas with altitudes greater than $1000 \mathrm{~m}$ a.s.l. (Flint and McArthur 2014).

Early records of the Sardinian Warbler in Cyprus dating back to the late 19th century suggested that it was then a winter visitor and passage migrant (Bucknill 1909). However, because of its increasing numbers in the summer, Sardinian Warbler was assumed to breed in Cyprus, even though evidence of its establishment was still lacking (Bannerman and Bannerman 1958). The first confirmed breeding record of the species in Cyprus was reported in 1992 in the northwest of the island (Frost 1994) followed by a breeding population identified in Pentadaktylos mountain range in the north of the island some years later (Pomeroy and Walsh 2000, Flint and McArthur 2014). Sardinian Warbler has since expanded its breeding range rapidly from the breeding population initially established in the west to now breed across most of Cyprus (Pomeroy and Walsh 2000, 2002, Jones 2006, Ieronymidou et al. 2012, Flint and McArthur 2014, Hellicar and Kirschel 2021). Based on recent reports, the total population of Sardinian Warbler in Cyprus is estimated between 60,000 and 110,000 breeding pairs (BirdLife International 2017), with their territories overlapping in several areas with those of Cyprus Warbler (Jones 2006, Ieronymidou et al. 2012). Yet, large numbers of Sardinian Warbler occur as migrants in Cyprus, either wintering on the island or as passage migrants (Shirihai et al. 2001, Flint and McArthur 2014). Across its range in Cyprus, Sardinian Warbler is more abundant at lower elevations, i.e., below $1000 \mathrm{~m}$ a.s.l., but breeding has been documented up to $1800 \mathrm{~m}$, and it can occur even higher, to 2400 $\mathrm{m}$, in its non-breeding range (Shirihai et al. 2001, Pomeroy and Walsh 2006, Ieronymidou et al. 2012). Sardinian Warbler exhibits a clear preference for dense shrub, tall and low maquis, sparse forests with bushy understory, olive groves, citrus crops, vineyards, suburban gardens and parks (Cody and Walter 1976). It is also a common colonizer of post-fire pioneer vegetation communities (Prodon 1988).

Spectacled Warbler is a resident species and partial migrant on the island of Cyprus (Shirihai et al. 2001, Flint and McArthur 2014). It exhibits a preference for areas with low mean annual rainfall (less than $450 \mathrm{~mm}$ / year), becoming absent from regions with annual precipitation over $450 \mathrm{~mm}$ (Flint and McArthur
2014). Where its range lies above the limit of $340 \mathrm{~mm}$ isohyet, it occasionally coexists with Cyprus Warbler (Flint and McArthur 2014). Across its range, Spectacled Warbler has been observed to breed syntopically with Sardinian Warbler (Cramp and Brooks 1992), such as on Kormakitis Peninsula in the northwest of the island (Flint and McArthur 2014). The species' population in Cyprus is estimated between 7,000 and 15,000 breeding pairs (BirdLife International 2017). Spectacled Warbler prefers habitats with low shrubs, low maquis areas with openings occupied by annual herbaceous vegetation, crop margins, and areas with halophytic vegetation (Shirihai et al. 2001).

\section{Population surveys}

Population surveys were carried out for the three Sylvia species breeding in Cyprus between 2013 and 2017 in 32 sample plots (Fig. 1). Plots were distributed in five regions of the island (Akamas, Kouklia, Akrotiri, Troodos, and Larnaka/ Ammochostos), with much emphasis on the Akrotiri Peninsula in the south, where the expansion of Sardinian Warbler had been predicted (Flint and McArthur 2014). Akamas comprises the northwest tip of the island that is protected from anthropogenic development. Akamas is primarily covered by undisturbed garrigue and tall maquis as well as dense or open pine forests. Kouklia is in the southwest of the island. Its landscape comprises a mixture of habitats including fragmented tall maquis, garrigues, and patches of pine forests. Much disturbance is evident from agricultural activities. Akrotiri includes the southernmost tip of the island. The area comprises a mosaic of habitats varying from salt marsh to grasslands, garrigue, maquis, and pine forests. Human disturbance at Akrotiri is high, incorporating a military base with a well-developed road network throughout. Troodos is the primary mountainous area on the island, with its highest peak at $1952 \mathrm{~m}$. Precipitation in the region is significantly higher compared to the other regions. Troodos retains dense pine forests and woody maquis. Larnaka/Ammochostos is a flat area in the east connected to the central plain. It is one of the most arid regions of the island. Cereal and potato cultivations are common there and dominate the landscape. Natural vegetation is sparse including low maquis, garrigue, and small patches of forests, mainly pine forests. Akrotiri and Larnaka/Ammochostos are the only regions with salt marsh.

Fig. 1. Survey plots were distributed across the island of Cyprus clustered in five areas: Akamas (triangles), Kouklia (open circles), Akrotiri (solid circles), Troodos (crosses), and Larnaka/Ammochostos (diamonds). Inset shows location of Cyprus in the Mediterranean Sea.

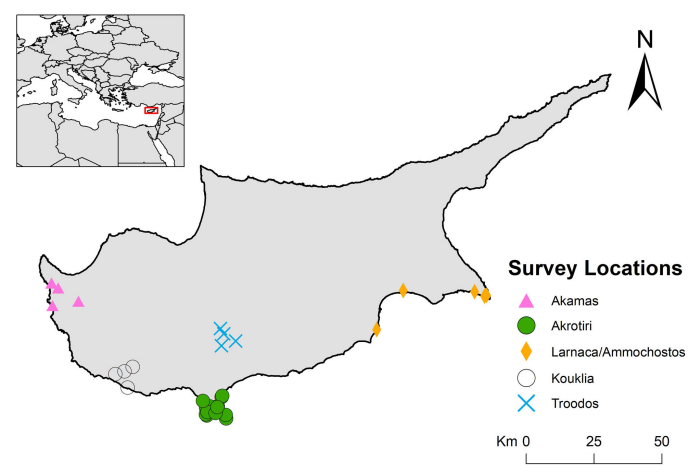


For each sample plot, surveys were performed during three seasons based on reports of their presence during those periods (Shirihai et al. 2001, Jones 2006): (a) pre-breeding season from mid-February to mid-March, (b) breeding season from mid-April to mid-June, and (c) wintering period from December to early January. Each plot was visited once in each season every year for the five years of this study, apart from in 2014 (year 2) when surveys were performed only during the wintering season because of unforeseen logistical reasons. Fieldwork targeted four natural habitat types where the three study species primarily occurred (Cramp and Brooks 1992, Shirihai et al. 2001, Jones 2006, Ieronymidou et al. 2012, Flint and McArthur 2014): (a) maquis (as defined in Davies et al. 2004) comprises evergreen sclerophyllous shrubs, with closed canopy structure and almost complete land cover. Trees are typically present as well as some annual plant species. Predominant species are Genista fasselata, Calicotome villosa, Juniperus phoenicea, Pistacia lentiscus, Olea europaea, and Ceratonia siliqua. (b) Pinus brutia forest comprises open woodland with Pinus brutia pines. (c) Garrigue (as defined in Davies et al. 2004), comprise low shrubland with extensive openings. Vernal species predominate and annual plants and geophytes are also abundant. Shrubs are found in patches with Cistus spp., Thymus capitatus, and Sarcopoterium spinosum the most common species. (d) salt marsh comprise perennial vegetation dominated by halophytes, mainly Salicornia spp. In addition, in this study we targeted anthropogenically disturbed, degraded habitats.

Sample plots were 2 ha rectangles $(100 \mathrm{~m} \times 200 \mathrm{~m}$; Bibby et al. 2000, Sutherland et al. 2004). Uniform plots of each habitat type were identified in the field and delineated using a handheld GPS device. Because of the high habitat fragmentation along the target regions (Zomeni and Vogiatzakis 2014; P. Panayides 2006, unpublished manuscript), random selection of plots would have resulted in mixtures of habitats, thus we opted for study area selection through work in the field to ensure uniform plots were targeted. Surveys were undertaken by two observers, who during the preliminary stages worked together to standardize survey procedure (Sutherland et al. 2004). Observers walked in a loop along each plot surveying up to $25 \mathrm{~m}$ each side of the route taken, recording the number of individuals of all three target species seen or heard. Because distinguishing Cyprus and Sardinian Warblers vocally can be challenging (Cramp and Brooks 1992, Shirihai et al. 2001), we typically persisted until visual confirmation. Any individuals that were not unambiguously identified as an adult individual of one of the species were not included in the results. Target species exhibit a cryptic behavior apart from territorial males during pre-breeding and breeding seasons (Shirihai et al. 2001). Thus, to increase detectability, we used playback (Bibby et al. 2000, Sutherland et al. 2004). To that end, songs of territorial males of each of the three target species were recorded in the field within or near the study sites for use as playback stimuli. Each playback comprised at least two sequential full songs of each species with their natural silent intervals inbetween. A handheld loudspeaker (Betron JRS40 Speaker, Benewy, $\mathrm{CH}$.) was used to broadcast recorded songs of the three species in rotation with intervals in-between sessions. Loudspeaker volume was standardized at the same fixed level (Sutherland et al. 2004). Because of differences in detectability between habitat types across plots, survey duration varied according to vegetation and topography (see Sutherland et al.
2004), lasting between 20 and 45 minutes. Although double counts cannot be completely eliminated, especially with the skulking behavior of our target species, the amount of time spent in each plot allowed us to observe the movements of individuals helping to minimize the extent of double counting. Visits to the plots were randomly scheduled and performed between 6:00 am and 12:00 pm. Fieldwork was suspended during adverse weather conditions such as heavy rain and strong winds in accordance with other studies (Hostetler and Main 2001, Stagoll et al. 2010).

Data on monthly total rainfall and average temperature for the duration of the study were obtained from the nearest meteorological station for each plot (Department of Meteorology 2018). We used rainfall and temperature data of the two-month period that preceded surveys, because the combination of increased soil moisture and relatively high ambient temperature triggers a gradual invertebrate population increase over the following weeks (Janzen 1973, Speight et al. 2008, Ramya et al. 2017, Sugawara et al. 2017). The Sylvia warblers we studied feed mostly on invertebrates, and invertebrate population fluctuations determine the timing of establishment of home ranges and territories (Jones 2006). When the survey took place after the middle of any given month then the temperature and precipitation values of the survey month and the immediately preceding month were considered. On the other hand, when the survey was before the middle of each month then the temperature and precipitation values of the two immediately preceding months were used.

\section{Statistical analysis}

To test which factors affect the presence of the three Sylvia species breeding in Cyprus, we fitted Poisson Generalized Linear Mixed Models (GLMMs) implemented in lme4 in R (Bates et al. 2015, $\mathrm{R}$ Core Team 2020). Specifically, we fitted separate models using the numbers of each of the three target species as response and including as fixed factors the season (pre-breeding, breeding, and wintering), area (Akamas, Kouklia, Akrotiri, Larnaka/ Ammochostos, and Troodos), habitat type (maquis, garrigue, pine forest, salt marsh, and disturbed mixture), and year (as a continuous variable), as well as interaction terms between season and area and also between habitat and year. In each model, we also included as fixed factors the numbers of individuals of each of the other two species to test for potential interspecific competition, and observer, to account for potential observer bias. In addition, we set site code as a random factor to account for variation across sampling sites in the models. All numeric covariates were centered and standardized (Schielzeth 2010). Best fit models were selected based on the lowest corrected Akaike Information Criterion (AICc) with those within $\triangle \mathrm{AICc}<2$ of the lowest scoring model considered equivalent (see Table A1.1). Selected models were validated with the testResiduals function provided in the DHARMa R package (Harting 2019). Graphical representations of fitted coefficients were produced using the Effects package (Fox and Weisberg 2018) in R.

We also performed an analysis for the relative importance and partitioning of variation for the covariates. To implement such analysis, we used a linear modeling approach following Essl et al. (2019); first, we square root transformed our response variable and fitted linear mixed-effects models (LMMs) equivalent to our GLMMs. We then ran linear models using all fixed effects of the GLMMs as independent variables after deducting the contribution of the linear random effects from the response 
values. We then calculated the relative importance of the predictors (Table A1.2) by performing $\mathrm{R}^{2}$ partitioning by averaging over orders (Lindeman 1980) using the calc.relimp function from the relaimpo R package (Grömping 2007).

Playback stimuli were used during the surveys to aid bird detection. This approach can, however, lead to a detection bias according to which female individuals might be underestimated because they tend to adopt a more cryptic behavior, particularly during the breeding season. Therefore, we ran a series of further GLMMs but using the number of males detected as the response variable instead of total birds. Comparing results of models with and without females included would provide insight into the magnitude of detection-bias that could result from the use of playbacks in surveys.

\section{RESULTS}

We completed 402 surveys within the 32 sample plots across the three seasons between 2013 and 2017. We found a total of 1138 individuals of the three target Sylvia species (Table 1), with the most abundant being Cyprus Warbler (590 individuals) followed by Sardinian Warbler (387 individuals) and Spectacled Warbler, which was the least represented in our surveys (161 individuals).

Table 1. Survey results throughout the duration of this study from 2013 to 2017. Most abundant was Cyprus Warbler (Sylvia melanothorax), followed by Sardinian Warbler (S. melanocephala) and Spectacled Warbler (S. conspicillata). We detected more males (M) than females (F).

\begin{tabular}{|c|c|c|c|c|c|c|c|c|c|}
\hline \multirow[t]{2}{*}{ Area } & \multicolumn{3}{|c|}{ Cyprus Warbler } & \multicolumn{3}{|c|}{$\begin{array}{l}\text { Sardinian } \\
\text { Warbler }\end{array}$} & \multicolumn{3}{|c|}{$\begin{array}{c}\text { Spectacled } \\
\text { Warbler }\end{array}$} \\
\hline & $\mathrm{M}$ & $\mathrm{F}$ & $\begin{array}{l}\text { Tot- } \\
\text { al }\end{array}$ & $\mathrm{M}$ & $\mathrm{F}$ & Total & $M$ & $\mathrm{~F}$ & Total \\
\hline Akamas & 43 & 3 & 46 & 74 & 9 & 83 & 0 & 0 & 0 \\
\hline Kouklia & 100 & 21 & 121 & 52 & 6 & 58 & 0 & 0 & 0 \\
\hline Akrotiri & 210 & 37 & 247 & 163 & 24 & 187 & 50 & 12 & 62 \\
\hline Troodos & 92 & 26 & 118 & 11 & 0 & 11 & 0 & 0 & 0 \\
\hline $\begin{array}{l}\text { Larnaka/ } \\
\text { Ammochostos }\end{array}$ & 45 & 13 & 58 & 41 & 7 & 48 & 82 & 17 & 99 \\
\hline Total & 490 & 100 & 590 & 341 & 46 & 387 & 132 & 29 & 161 \\
\hline
\end{tabular}

Model validation with DHARMa confirmed the reliability of our estimates for the models of the three species (Table A1.3). We show that Cyprus Warbler significantly declined over the five years of the study (Table 2, Fig. 2, Table A1.3). We found that Cyprus Warbler was highly affected by habitat, which explained $\sim 60 \%$ of the variation in the model (Table A1.2). Specifically, it was present in significantly lower numbers in disturbed mixture, garrigue, pine forest, and salt marsh habitats than in maquis (Fig. 3 ), and a negative interaction of disturbed mixture with year (marginally non-significant when analyzing males only, Table A1.4a), and positive interaction of garrigue with year, indicated that Cyprus warbler declined significantly more over time in disturbed habitat (and less in garrigue) than in maquis. Cyprus Warbler was also negatively associated with both Spectacled Warbler and Sardinian Warbler abundances. We found no differences between areas in Cyprus Warbler nor in the interaction of area with season (Fig. 4). The best supported model for Cyprus Warbler, however, included area and its interaction with season (Table A1.3), but an equivalent model $(\triangle \mathrm{AICc}=0.75)$, excluding those 12 non-significant areas and its interaction with season effects, revealed significantly lower numbers of Cyprus Warbler in winter compared to the breeding season (Table 2).

Table 2. Generalized Linear Mixed Model (GLMM) output for the effect of season, area, habitat type, year, and congener abundance, as well as the interactions of year with habitat, and season with area, on numbers of adult individuals of each Sylvia species that breeds in Cyprus, across 402 surveys. Significant results are presented in bold font.

\begin{tabular}{lcccc}
\hline \hline (a) Cyprus warbler (Sylvia melanothorax) & & & \\
Random effects: & Variance & Std. dev & & \\
Site code & 0.706 & 0.840 & & \\
Fixed effects: & Estimate & Std. Error & $z$ & $p$ \\
Intercept & 1.165 & 0.330 & 3.530 & $<\mathbf{0 . 0 0 1}$ \\
Breeding & -0.007 & 0.091 & -0.080 & 0.936 \\
Wintering & -0.829 & 0.118 & -7.008 & $<\mathbf{0 . 0 0 1}$ \\
Disturbed mixture & -1.251 & 0.479 & -2.612 & $\mathbf{0 . 0 0 9}$ \\
Garrigue & -1.396 & 0.481 & -2.900 & $\mathbf{0 . 0 0 3}$ \\
Pine Forest & -1.197 & 0.473 & -2.530 & $\mathbf{0 . 0 1 1}$ \\
Salt marsh & -4.699 & 1.094 & -4.294 & $<\mathbf{0 . 0 0 1}$ \\
Year & -0.331 & 0.061 & -5.354 & $<\mathbf{0 . 0 0 1}$ \\
Spectacled warbler & -0.339 & 0.161 & -2.467 & $\mathbf{0 . 0 1 3}$ \\
Sardinian warbler & -0.160 & 0.055 & -2.894 & $\mathbf{0 . 0 0 3}$ \\
Disturbed mixture $\times$ year & -0.236 & 0.113 & -2.092 & $\mathbf{0 . 0 3 6}$ \\
Garrigue $\times$ year & 0.269 & 0.117 & 2.283 & $\mathbf{0 . 0 2 2}$ \\
Pine forest $\times$ year & 0.183 & 0.109 & 1.682 & 0.092 \\
Salt marsh $\times$ year & 0.993 & 0.945 & 1.051 & 0.293
\end{tabular}

Salt marsh $\times$ year $\quad 0.993 \quad 0.945 \quad 1.051 \quad 0.293$

(b) Sardinian warbler (S. melanocephala)

$\begin{array}{lcccc}\text { Random effects: } & \text { Variance } & \text { Std. dev } & & \\ \text { Site code } & 0.094 & 0.307 & & p \\ \text { Fixed effects: } & \text { Estimate } & \text { Std. Error } & z & <\mathbf{0 0 1} \\ \text { Intercept } & 1.092 & 0.268 & 4.072 & <\mathbf{0 . 0 0 1} \\ \text { Breeding } & -0.735 & 0.278 & -2.639 & \mathbf{0 . 0 0 8} \\ \text { Wintering } & -0.688 & 0.256 & -2.683 & \mathbf{0 . 0 0 7} \\ \text { Akrotiri } & -0.708 & 0.279 & -2.535 & \mathbf{0 . 0 1 1} \\ \text { Cape Greko } & -1.691 & 0.467 & -3.618 & <\mathbf{0 . 0 0 1} \\ \text { Kouklia } & -1.213 & 0.427 & -2.839 & \mathbf{0 . 0 0 4} \\ \text { Troodos } & -2.540 & 0.641 & -3.959 & <\mathbf{0 . 0 0 1} \\ \text { Disturbed mixture } & 0.035 & 0.221 & 0.159 & 0.873 \\ \text { Garrigue } & -1.103 & 0.255 & -4.324 & <\mathbf{0 . 0 0 1} \\ \text { Pine Forest } & -0.881 & 0.240 & -3.662 & <\mathbf{0 . 0 0 1} \\ \text { Salt marsh } & -4.095 & 0.908 & -4.510 & <\mathbf{0 . 0 0 1} \\ \text { Year } & -0.216 & 0.120 & -1.794 & 0.072 \\ \text { Cyprus warbler } & -0.159 & 0.069 & -2.310 & \mathbf{0 . 0 2 0} \\ \text { Observer } 2 & 0.485 & 0.193 & 2.513 & \mathbf{0 . 0 1 1} \\ \text { Breeding: Akrotiri } & 0.314 & 0.347 & 0.900 & 0.365 \\ \text { Wintering: Akrotiri } & 0.973 & 0.307 & 3.163 & \mathbf{0 . 0 0 1} \\ \text { Breeding: Cape Greko } & 0.325 & 0.645 & 0.505 & 0.613 \\ \text { Wintering: Cape Greko } & 2.112 & 0.485 & 4.354 & <\mathbf{0 . 0 0 1} \\ \text { Breeding: Kouklia } & 0.993 & 0.497 & 1.996 & \mathbf{0 . 0 4 5} \\ \text { Wintering: Kouklia } & 1.513 & 0.443 & 3.415 & <\mathbf{0 . 0 0 1} \\ \text { Breeding: Troodos } & 0.416 & 0.951 & 0.437 & 0.662 \\ \text { Wintering: Troodos } & 1.169 & 0.749 & 1.562 & 0.118 \\ \text { Disturbed mixture } \times \text { year } & 0.161 & 0.119 & 1.354 & 0.175 \\ \text { Garrigue } \times \text { year } & 0.309 & 0.162 & 1.907 & 0.056 \\ \text { Pine forest } \times \text { year } & 0.420 & 0.154 & 2.718 & \mathbf{0 . 0 0 6} \\ \text { Salt marsh } \times \text { year } & 1.048 & 0.851 & 1.232 & 0.218\end{array}$

(c) Spectacled warbler (S. conspicillata)

\begin{tabular}{lcccc} 
Random effects: & Variance & Std. dev & & \\
Site code & 20.140 & 4.488 & & \\
Fixed effects: & Estimate & Std. Error & $z$ & $p$ \\
Intercept & -7.772 & 2.323 & -3.345 & $<\mathbf{0 . 0 0 1}$ \\
Breeding & 0.440 & 0.208 & 2.115 & $\mathbf{0 . 0 3 4}$ \\
Wintering & 0.357 & 0.205 & 1.744 & 0.081 \\
Disturbed mixture & -0.236 & 2.566 & -0.092 & 0.926 \\
Garrigue & 1.186 & 2.514 & 0.472 & 0.636 \\
Pine Forest & -0.473 & 2.594 & -0.182 & 0.855 \\
Salt marsh & 7.330 & 3.228 & 2.270 & $\mathbf{0 . 0 2 3}$ \\
Observer 2 & 0.947 & 0.154 & 5.945 & $<\mathbf{0 . 0 0 1}$ \\
\hline
\end{tabular}


Fig. 2. Plots illustrating fitted coefficients (black line) and 95\% confidence intervals (shaded gray) of the best supported Generalized Linear Mixed Model (GLMM) for each species including year as a fixed factor in the model. Cyprus Warbler, Sylvia melanothorax (a) declined significantly over the period, while numbers of (b) Sardinian Warbler, S. melanocephala and (c) Spectacled Warbler, S. conspicillata were stable. Y axis is on a $\log$ scale.

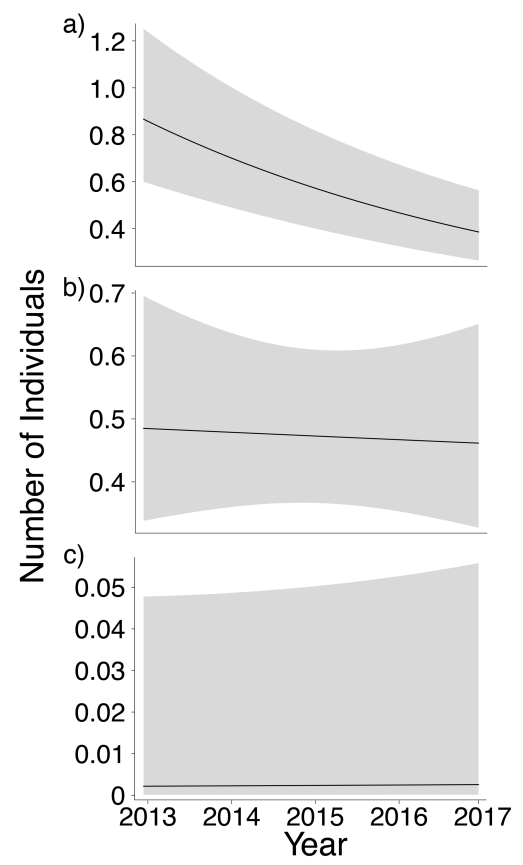

Fig. 3. Mean number of individuals $( \pm S E)$ of each species per survey by habitat. Cyprus Warbler ( $S$. melanothorax; dark gray) occurs in significantly greater numbers in maquis than in other habitats, while Sardinian Warbler ( $S$. melanocephala; mid gray) occurs in similar numbers in disturbed habitats as in maquis. Spectacled Warbler ( $S$. conspicillata; light gray) occurs mostly in salt marsh.

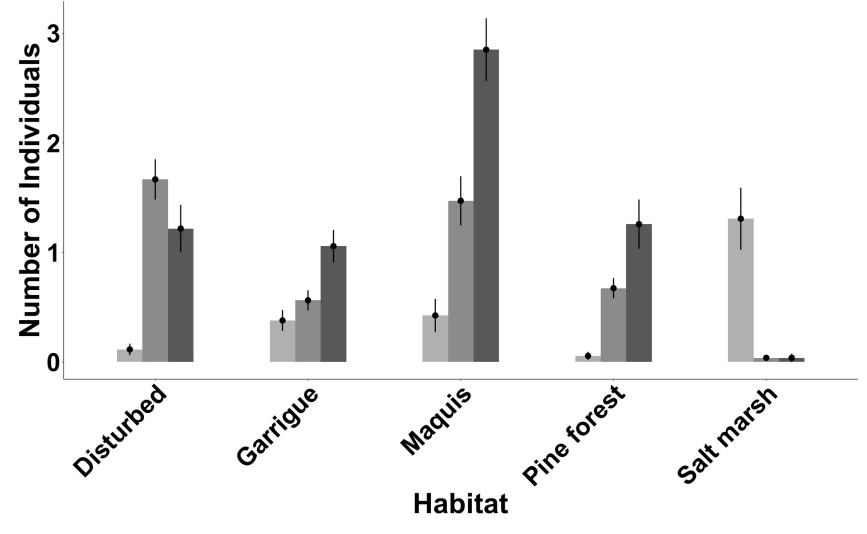

Fig. 4. Mean abundances of each species ( \pm SE) across areas: (a) Akamas, (b) Akrotiri, (c) Larnaca/Ammochostos, (d) Kouklia, (e) Troodos, and between seasons. Sardinian Warbler (Sylvia melanocephala; mid gray) varies most by area and season of the three species, occurring in higher numbers in the pre-breeding season, and higher numbers overall in Akamas, but relatively lower numbers there in winter compared to Kouklia and Larnaca/Ammochostos compared to their relative abundances among those areas in the pre-breeding season. Cyprus Warbler ( $S$. melanothorax; dark gray) differs in abundances only in Akrotiri, where it occurs in lower numbers in winter compared to its relative abundance between seasons in Akamas. Spectacled Warbler ( $S$. conspicillata; light gray) was absent from surveys in three areas but occurred in most numbers in Larnaca/Ammochostos and was also present in Akrotiri, with numbers stable across seasons.
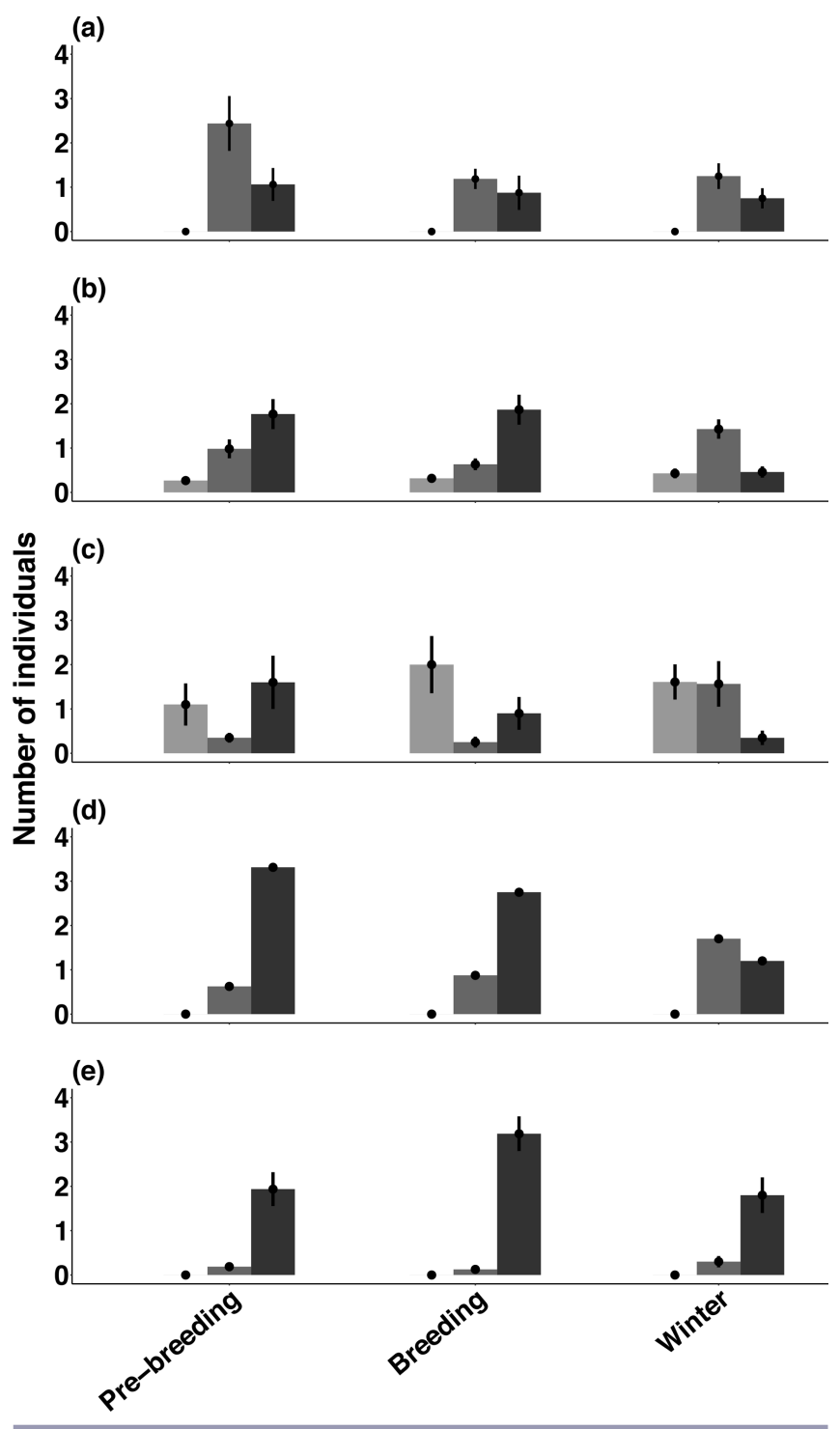
Sardinian Warbler occurred in significantly lower numbers during the breeding and wintering season compared to the pre-breeding season (Table 2, Fig. 4) and in all other areas compared to Akamas (Fig. 4). Our results also suggest that Sardinian Warbler occurred in relatively higher numbers during winter in Akrotiri and Larnaka/Ammochostos, and during winter and the breeding season (non-significant for males only) in Kouklia, than in Akamas, when compared with their relative abundances in the pre-breeding season. Habitat revealed to be the most influent variable in the best supported model for Sardinian Warbler, explaining approximatively $50 \%$ of the variation (Table A1.2). However, in contrast to Cyprus Warbler, Sardinian Warbler occurred in lower numbers in garrigue, pine forest, and salt marsh compared to maquis; we did not find significant differences between their numbers in maquis and disturbed, mixed habitats (Fig. 3). But Sardinian Warbler also occurred in lower numbers where Cyprus Warbler occurred in higher abundances, and although there was no overall effect of year, it did occur in relatively higher numbers in pine forest than in maquis over time. In addition, there was an effect of observer, with observer 2 detecting relatively higher numbers of Sardinian Warbler compared to observer 1 .

Spectacled Warbler was found in higher numbers in the breeding season compared to pre-breeding (non-significant for males only) and exhibited a highly significant preference for salt marsh habitat (with habitat explaining more than $90 \%$ of the variation in the model, see Table A1.2) over maquis (Table 2), while observer 2 again observed more Spectacled Warblers compared to observer 1.

Our results also show that the models with only male individuals of the three Sylvia species as response variable produced similar results to the models that included both males and females (Table A1.5). The only differences were those that might represent Type II errors resulting from smaller sample sizes, suggesting that the use of playback is unlikely to have significantly biased bird detection among the sexes during our surveys.

\section{DISCUSSION}

The present study is the first to comparatively assess the populations of all three Sylvia species breeding in Cyprus. Our results demonstrated a significant overall decline in the populations of Cyprus Warbler from 2013 to 2017, in line with and continuing on from the findings of previous studies in Cyprus (Pomeroy and Walsh 2000, Flint and McArthur 2014, Pomeroy et al. 2016, Hellicar and Kirschel 2021). On the other hand, Sardinian and Spectacled Warbler maintained stable populations throughout the study period.

The expected association of Cyprus Warbler with undisturbed maquis habitats (Cramp and Brooks 1992, Shirihai et al. 2001) represents a potential explanation for its decline. Indeed, across Cyprus, maquis as well as other natural habitats are negatively impacted by urbanization, wildfires and fragmentation (Vogiatzakis et al. 2008). These factors increase the pressure on Cyprus Warbler, which has to cope with smaller scattered patches of preferred habitat (Opdam 1991). Small fragmented habitats can increase the risk of local population decline (Fahrig 2002). Even in years with high breeding success when Cyprus Warbler can potentially exhibit local increases (Jones 2006), part of the population is forced to disperse into the nearby fragmented habitat patches thus might be exposed to increased predation and decreased foraging success (Fahrig 2003). The decline we found in disturbed habitat is especially concerning, coupled with our results that suggest it occurs in lower numbers where Sardinian warbler is abundant, indicative of competition. By contrast, Cyprus Warbler may benefit from low intensity grazing within scrub habitat (Hellicar and Kirschel 2021), and high nature value farming practices (Hellicar et al. 2019).

Sardinian Warbler might take advantage of habitat fragmentation and expansion of disturbed mixtures, something that has been found to benefit some species (Fahrig 2003). Indeed, Sardinian Warbler was found in lower densities in natural habitats compared to Cyprus Warbler but occurred relatively more frequently in disturbed mixtures (Fig. 3), where the endemic may have declined more dramatically because of the combined effects of disturbance and competition. These differences in species densities might indicate that the decline of the Cyprus Warbler is not solely attributed to higher abundances of a newly established congener (Opdam and Wascher 2004), Sardinian Warbler, whose population at sites included in the study was stable from 2013 to 2017. But the presence of Sardinian Warbler alone might still negatively affect Cyprus Warbler populations, either through direct aggressive interactions or indirect effects such as disease spread (Jones 2006), or apparent competition (see Holt and Bonsall 2017).

Spectacled Warbler's preference for salt marsh habitat over maquis, and the avoidance of salt marsh by Cyprus Warbler, suggests that their different evolutionary histories constrained them from using similar habitats. As a result, they have historically coexisted in Cyprus (Cramp and Brooks 1992, Shirihai et al. 2001, Flint and McArthur 2014), independently of one another with Spectacled Warbler breeding in the most arid areas of the island (Flint and McArthur 2014), whereas Cyprus Warbler's distribution is confined by the $340 \mathrm{~mm}$ isohyet, thus avoiding the most arid regions.

Variation in species abundance among areas was really only evident in the recent colonist. The significantly lower abundance of Sardinian Warbler in all other areas compared to Akamas is indicative of its initial colonization and breeding population establishment there (Frost 1994, Shirihai et al. 2001, Flint and McArthur 2014, Pomeroy et al. 2016). Twenty-five years after its initial colonization of Cyprus in the early 1990s (Pomeroy and Walsh 2000), Sardinian Warbler has established a large breeding population on the island (Stylianou 2015) and is currently in an advanced colonization stage (Ricciardi et al. 2013). Its population stronghold remains in the west, but following dispersal southwards along the coast, it has progressively colonized areas to the east (Flint and McArthur 2014) where it is now a common breeder (Stylianou 2015). Sardinian Warbler is also a common wintering species in Cyprus (Shirihai et al. 2001, Flint and McArthur 2014), yet we found it is most abundant during the prebreeding season in Akamas than in the breeding and wintering seasons. Cyprus resides on one of the main Afro-Palearctic migration routes for many species (Hahn et al. 2009), including Sylvia warblers such as the Sardinian Warbler (Shirihai et al. 2001, Doswald et al. 2009). Sardinian Warblers migrate from Africa and fly over Cyprus (Shirihai et al. 2001), when they possibly use the 
island as a stopover site, joining resident and late wintering birds, thus increasing local abundances. The migrating birds funnel through the Akamas Peninsula during spring where extensive maquis habitat might temporarily sustain the locally increased warbler populations. Sardinian warbler might also exhibit some local wintering movements, moving away from the northern Akamas site further south to Kouklia, Akrotiri, and Larnaca/ Ammochostos. Nevertheless, our results indicate a lower abundance of Sardinian Warbler at higher elevations, consistent with it preferring lower elevations (Pomeroy and Walsh 2002, Ieronymidou et al. 2012).

There has been much debate regarding whether interspecific competition plays an important role in governing Sylvia warbler populations and their distributions (Cody and Walter 1976, Martin and Thibault 1996). Previous studies have suggested the presence of other breeding congeners in Cyprus might significantly affect population dynamics of the endemic Cyprus Warbler (Pomeroy and Walsh 2000, Pomeroy et al. 2016). In addition to differences in abundances attributed to habitats, seasons, and areas, we found a negative relationship between Sardinian Warbler and Cyprus Warbler abundances. Both Cyprus and Sardinian Warblers exhibited a preference for maquis habitat, yet consistent with Hellicar and Kirschel (2021) focusing on grazed natural scrub, we found that relative numbers of Cyprus and Sardinian Warbler were negatively associated with one another's density. Previous studies found no evidence of resource competition between Cyprus and Sardinian warbler in Cyprus (Jones 2006, Ieronymidou et al. 2012), but our results suggest there might be competition, though its effect appears to be comparatively much smaller on Cyprus Warbler numbers than that of habitat disturbance. A relative increase in Cyprus Warbler over time in garrigue might even represent displacement from maquis and recently disturbed mixtures.

Thus far no study has found evidence of direct interference competition between breeding Sylvia warblers in Cyprus, though this is something that needs further study. Based on the phenotypic similarity in plumage and song between Cyprus and Sardinian Warbler, direct interference competition might occur between the species, which studies in other phenotypically similar and closely related species of birds have shown can result in character displacement or competitive exclusion (e.g., Kirschel et al. 2009, 2019, 2020). Indeed, Cyprus Warbler has been shown to be attracted by playback of Sardinian Warbler song in Cyprus (Sebastianelli et al. 2020). Further work is thus needed to explore the possible effects of direct interactions between these Sylvia warbler species and how they might influence their coexistence and population dynamics. Our study does suggest however that habitat disturbance may be having a profound effect on Cyprus warbler numbers, with Sardinian warbler potentially benefiting as a result. The impact of habitat degradation on birds has long been established, and the insular endemic Cyprus warbler appears to be yet another species vulnerable to ongoing disturbance of natural habitats, compounding any possible competition with its recent colonizer.

Natural colonization events explain many of the present distributions of species, and ensuing interactions can lead to local changes in habitat use and might even lead to extinction, but the time scales of such taxon cycles are seldom known. Much research has focused on the effect on insular endemics of species introduced to islands, with endemic species often disappearing within decades (Freed and Cann 2009). The influence of natural colonizations on insular endemics could be similar, but our study suggests that habitat disturbance may play a greater role than competition from a natural colonization on insular species range contraction and decline, though together these factors may provide added pressure on island endemics.

Responses to this article can be read online at: https://www.ace-eco.org/issues/responses.php/1937

\section{Acknowledgments:}

We are grateful to P. Minas for assistance with data analysis in the early stages of our study. We would also like to thank $C$. Ieronymidou for the valuable resources she provided to us on species distribution and status information from Birdlife Cyprus data. We thank subject editor Wayne Thogmartin and three anonymous reviewers for comments that helped us improve the manuscript. This work was supported by A. G. Leventis Foundation Scholarships (NP, $T G H, M S)$ and a University of Cyprus Evagoras scholarship (MS).

\section{LITERATURE CITED}

Andrén, H. 1994. Effects of habitat fragmentation on birds and mammals in landscapes with different proportions of suitable habitat: a review. Oikos 71:355-366. https://doi.org/10.2307/3545823

Bannerman, D. A., and W. M. Bannerman. 1958. Birds of Cyprus. Oliver \& Boyd, London, UK.

Bates, D., M. Maechler, B. Bolker, and S. Walker. 2015. Fitting linear mixed-effects models using lme4. Journal of Statistical Software 67:1-48. https://doi.org/10.18637/jss.v067.i01

Bellard, C., P. Cassey, and T. M. Blackburn. 2016. Alien species as a driver of recent extinctions. Biology Letters 12(2). https:// doi.org/10.1098/rsbl.2015.0623

Bibby, C., N. Burgess, D. Hill, and S. Mustoe. 2000. Bird census techniques. Second edition. Academic Press, London, UK.

BirdLife International. 2017. European birds of conservation concern: populations, trends and national responsibilities. BirdLife International, Cambridge, UK.

Blondel, J. 2000. Evolution and ecology of birds on islands: trends and prospects. Vie et Milieu/Life \& Environment, Observatoire Océanologique - Laboratoire Arago 50(4):205-220.

Blondel, J., F. Catzeflis, and P. Perret. 1996. Molecular phylogeny and the historical biogeography of the warblers of the genus Sylvia (Aves). Journal of Evolutionary Biology 9:871-891. https:// doi.org/10.1046/j.1420-9101.1996.9060871.x

Braz, A. G., C. E. de Viveiros Grelle, M. de Souza Lima Figueiredo, and M. de M. Weber. 2020. Interspecific competition 
constrains local abundance in highly suitable areas. Ecography 43 (10):1560-1570. https://doi.org/10.1111/ecog.04898

Bucknill, J. A. 1909. On the ornithology of Cyprus. Ibis Ninth Series/XII/XXIX:569-613.

Case, T. J., and M. L. Cody, 1987. Testing theories of island biogeography. American Scientist 75(4):402-411.

Cody, M. L. 1978. Habitat selection and interspecific territoriality among the Sylviid warblers of England and Sweden. Ecological Monographs 48:351-396. https://doi.org/10.2307/2937239

Cody, M. L., and H. Walter. 1976. Habitat selection and interspecific interactions among Mediterranean Sylviid warblers. Oikos 27:210-238. https://doi.org/10.2307/3543900

Cramp, S., and D. J. Brooks, editors. 1992. The birds of the Western Palearctic, vol. VI. Handbook of the birds of Europe, the Middle East and North Africa. Oxford University Press, Oxford, UK.

Croonquist, M. J. and R. P. Brooks. 1993. Effects of habitat disturbance on bird communities in riparian corridors. Journal of Soil and Water Conservation 48(1):65-70.

Davies, E. C., D. Moss, and O. M. Hill. 2004. EUNIS habitat classification revised 2004. Report to: European Environment Agency-European Topic Centre on Nature Protection and Biodiversity, Copenhagen, Denmark.

Department of Meteorology. 2018. Monthly average precipitation in Cyprus. Department of Meteorology. Ministry of Agriculture, Rural Development and Environment, Republic of Cyprus, Nicosia, Cyprus.

Dhondt, A. A. 2012. Interspecific competition in birds. Oxford University Press, New York, New York, USA.

Doswald, N., S. G. Willis, Y. C. Collingham, D. J. Pain, R. E. Green, and B. Huntley. 2009. Potential impacts of climatic change on the breeding and non-breeding ranges and migration distance of European Sylvia warblers. Journal of Biogeography 36:1194-1208. https://doi.org/10.1111/j.1365-2699.2009.02086.x

Essl, F., W. Dawson, H. Kreft, J. Pergl, P. Pyšek, M. van Kleunen, P. Weigelt, T. Mang, S. Dullinger, B. Lenzner, et al. 2019. Drivers of the relative richness of naturalized and invasive plant species on Earth. AoB Plants 11:plz051. https://doi.org/10.1093/aobpla/ plz051

European Parliament. 2009. Directive 2009/147/EC of the European Parliament and the Council of 30 November 2009 on the conservation of wild birds. Official Journal of the European Union L20/7-25.

Fahrig, L. 2001. How much habitat is enough? Biological Conservation 100:65-74. https://doi.org/10.1016/S0006-3207(00) 00208-1

Fahrig, L. 2002. Effect of habitat fragmentation on the extinction threshold: a synthesis. Ecological Applications 12:346-353. https://doi.org/10.1890/1051-0761(2002)012[0346:eohfot]2.0.co;2

Fahrig, L. 2003. Effects of habitat fragmentation on biodiversity. Annual Review of Ecology, Evolution, and Systematics 34 (1):487-515. https://doi.org/10.1146/annurev.ecolsys.34.011802.132419
Flint, P., and A. McArthur. 2014. Is the Sardinian Warbler Sylvia melanocephala displacing the endemic Cyprus Warbler $S$. melanothorax in Cyprus? Sandgrouse 36:63-109.

Flint, P., and P. Stewart. 1992. The birds of Cyprus. British Ornithologists' Union, Peterborough, UK.

Fox, J., and S. Weisberg. 2018. Visualizing fit and lack of fit in complex regression models with predictor effect plots and partial residuals. Journal of Statistical Software 87(9). https://doi. org/10.18637/jss.v087.i09

Freed, L. A., and R. L. Cann. 2009. Negative effects of an introduced bird species on growth and survival in a native bird community. Current Biology 19:1736-1740. https://doi. org/10.1016/j.cub.2009.08.044

Frost, R. 1994. The Sardinian warbler breeding in Cyprus. Cyprus Ornithological Society 41st Annual Report:79-81.

Grether, G. F., C. N. Anderson, J. P. Drury, A. N. G. Kirschel, N. Losin, K. Okamoto, and K. S. Peiman. 2013. The evolutionary consequences of interspecific aggression. Annals of the New York Academy of Sciences 1289:48-68. https://doi.org/10.1111/ nyas. 12082

Grömping, U. 2007. Relative importance for linear regression in $\mathrm{R}$ : the package relaimpo. Journal of Statistical Software 17:1-27. https://doi.org/10.18637/jss.v017.i01

Guillaumet, A., and R. Prodon. 2011. Avian succession along ecological gradients: insight from species-poor and species-rich communities of Sylvia warblers. Current Zoology 57:307-317. https://doi.org/10.1093/czoolo/57.3.307

Hahn, S., S. Bauer, and F. Liechti. 2009. The natural link between Europe and Africa - 2.1 billion birds on migration. Oikos 118:624-626. https://doi:10.1111/j.1600-0706.2008.17309.x

Harting, F. 2019. DHARMa: residual diagnostics for hierarchical (multi-level / mixed) regression models. [online] URL:https:// CRAN.R-project.org/package $=$ DHARMa

Hellicar, M. A., J. Honold, and A. N. G. Kirschel. 2019. Comparison of land cover and farming intensity-based models for mapping high nature value farmland in Cyprus. Bird Study 66:317-328. https://doi.org/10.1080/00063657.2019.1684875

Hellicar, M., and A. N. G. Kirschel. 2021. Grazing pressure and the interaction dynamics of the endemic Cyprus Warbler Sylvia melanothorax and its recently colonising congener the Sardinian Warbler S. melanocephala. Bird Conservation International 31:239-254. https://doi.org/10.1017/S0959270920000180

Hoffmann, B. D., and F. Courchamp. 2016. Biological invasions and natural colonisations: are they that different? NeoBiota 29:1-14. https://doi.org/10.3897/neobiota.29.6959

Holt, R. D., and M. B. Bonsall. 2017. Apparent competition. Annual Review of Ecology, Evolution, and Systematics 48:447-471. https://doi.org/10.1146/annurev-ecolsys-110316-022628

Hostetler, M. E., and M. B. Main. 2001. Florida monitoring program: point count method to survey birds. University of Florida Cooperative Extension Service, Institute of Food and Agriculture Sciences, EDIS, Gainesville, Florida. 
Ieronymidou, C., N. J. Collar, and P. M. Dolman. 2012. Endemic Cyprus Warbler Sylvia melanothorax and colonizing Sardinian Warbler Sylvia melanocephala show different habitat associations. Ibis 154:248-259. https://doi.org/10.1111/j.1474-919X.2011.01211. $\mathrm{x}$

Janzen, D. H. 1973. Sweep samples of tropical foliage insects: effects of seasons, vegetation types, elevation, time of day, and insularity. Ecology 54:687-708. https://doi.org/10.2307/1935359

Jehl, J. R., and K. C. Parkes. 1983. "Replacements" of landbird species on Socorro Island, Mexico. Auk 100:551-559. https://doi. org/10.1093/auk/100.3.551

Jones, V. R. 2006. Comparative ecology of the endemic Cyprus Warbler and the congeneric Sardinian Warbler: implications of recent coexistence. Dissertation. University of Cambridge, Cambridge, UK.

Kirschel, A. N. G., D. T. Blumstein, and T. B. Smith. 2009. Character displacement of song and morphology in African tinkerbirds. Proceedings of the National Academy of Sciences of the United States of America 106:8256-8261. https://doi. org/10.1073/pnas.0810124106

Kirschel, A. N. G., E. C. Nwankwo, N. Seal, and G. F. Grether. 2020. Time spent together and time spent apart affect song, feather colour and range overlap in tinkerbirds. Biological Journal of the Linnean Society 129:439-458. https://doi.org/10.1093/ biolinnean/blz191

Kirschel, A. N. G., N. Seddon, and J. A. Tobias. 2019. Rangewide spatial mapping reveals convergent character displacement of bird song. Proceedings of the Royal Society B: Biological Sciences 286(1902). https://doi.org/10.1098/rspb.2019.0443

Lindeman, R. H. 1980. Introduction to bivariate and multivariate analysis. Scott Foresman, Glenview, Illinois, USA.

Martin, J.-L., and J.-C. Thibault. 1996. Coexistence in Mediterranean warblers: ecological differences or interspecific territoriality? Journal of Biogeography 23(2):169-178. https://doi. org/10.1111/j.1365-2699.1996.00028.X

Mayr, E. 1965. Avifauna: turnover on islands. Science 150:1587-1588. https://doi.org/10.1126/science.150.3703.1587

Nackley, L. L., A. G. West, A. L. Skowno, and W. J. Bond. 2017. The nebulous ecology of native invasions. Trends in Ecology and Evolution 32:814-824. https://doi.org/10.1016/j.tree.2017.08.003

Newton, I. 2003. Speciation and biogreography of birds. Academic, London, UK.

Opdam, P. 1991. Metapopulation theory and habitat fragmentation: a review of holarctic breeding bird studies. Landscape Ecology 5:93-106. https://doi.org/10.1007/BF00124663

Opdam, P., and D. Wascher. 2004. Climate change meets habitat fragmentation: linking landscape and biogeographical scale levels in research and conservation. Biological Conservation 117:285-297. https://doi.org/10.1016/j.biocon.2003.12.008

Pomeroy, D., and F. Walsh. 2000. Is Sardinian Warbler Sylvia melanocephala displacing Cyprus Warbler $S$. melanothorax in Cyprus? Sandgrouse 22:44-49.
Pomeroy, D., and F. Walsh. 2002. A European endemic warbler under threat? Population changes in Sylvia warblers on the island of Cyprus. Oryx 36:342-348. https://doi.org/10.1017/S0030605302000686

Pomeroy, D., and F. Walsh. 2006. Bird censusing and monitoring on Cyprus. Sandgrouse 28:34-43.

Pomeroy, D., F. Walsh, P. Flint, M. Hellicar, and P. Shaw. 2016. A sustained decline in Cyprus Warbler Sylvia melanothorax numbers in western Cyprus, coinciding with the colonisation of its breeding range by the Sardinian Warbler $S$. melanocephala. Bird Conservation International 26:436-450. https://doi. org/10.1017/S0959270915000337

Pons, P., J. M. Bas, R. Prodon, N. Roura-Pascual, and M. Clavero. 2008. Territory characteristics and coexistence with heterospecifics in the Dartford warbler Sylvia undata across a habitat gradient. Behavioral Ecology and Sociobiology 62:1217-1228. https://doi. org/10.1007/s00265-008-0550-3

Prodon, R. 1988. Dynamique des systemes avifaune: vegetation apres deprise rurale et incendies dans les pyrenees mediterraneennes silicieuses. Dissertation. University Pierre et Marie Curie, Paris, France.

R Core Team. 2020. R: A language and environment for statistical computing. R Foundation for Statistical Computing, Vienna, Austria.

Ramya, R. S., M. G. Kumar, and M. Ranjith. 2017. Influence of weather parameters on seasonal abundance of arthropods in a floricultural ecosystem. Journal of Entomology and Zoology Studies 5:1672-1676.

Ricciardi, A., M. F. Hoopes, M. P. Marchetti, and J. L. Lockwood. 2013. Progress toward understanding the ecological impacts of nonnative species. Ecological Monographs 83:263-282. https:// doi.org/10.1890/13-0183.1

Ricklefs, R. E., and G. W. Cox. 1972. Taxon cycles in the West Indian avifauna. American Naturalist 106:948. https://doi. org/10.1086/282762

Schielzeth, H. 2010. Simple means to improve the interpretability of regression coefficients. Methods in Ecology and Evolution 1:103-113. https://doi.org/10.1111/j.2041-210x.2010.00012.x

Sebastianelli, M., G. Savva, M. Moysi, and A. N. G. Kirschel. 2020. Tape lures swell bycatch on a Mediterranean island harbouring illegal bird trapping. Biology Letters 16(9). https:// doi.org/10.1098/rsbl.2020.0458

Shirihai, H., G. Gargallo, and A. J. Helbig. 2001. Sylvia warblers. Identification, taxonomy and phylogeny of the genus Sylvia. Helm Identification Guides, London, UK.

Speight, M. R., M. D. Hunter, and A. D. Watt. 2008. Ecology of insects: concepts and applications. Wiley-Blackwell, Hoboken, New Jersey, USA.

Spurgin, L. G., J. C. Illera, T. H. Jorgensen, D. A. Dawson, and D. S. Richardson. 2014. Genetic and phenotypic divergence in an island bird: isolation by distance, by colonization or by adaptation? Molecular Ecology 23:1028-1039. https://doi. org/10.1111/mec. 12672 
Stagoll, K., A. D. Manning, E. Knight, J. Fischer, and D. B. Lindenmayer. 2010. Using bird-habitat relationships to inform urban planning. Landscape and Urban Planning 98:13-25. https://doi.org/10.1016/j.landurbplan.2010.07.006

Stylianou, J. 2015. Cyprus bird report. BirdLife Cyprus, Nicosia, Cyprus.

Sugawara, R., M. S. Ullah, C. C. Ho, A. Gökçe, H. Chi, and T. Gotoh. 2017. Temperature-dependent demography of two closely related predatory mites Neoseiulus womersleyi and $N$. longispinosus (Acari: Phytoseiidae). Journal of Economic Entomology 110(4):1533-1546. https://doi.org/10.1093/jee/tox177

Sutherland, W. J., N. Ian, and R. E. Green. 2004. Bird ecology and conservation: a handbook of techniques. Oxford University Press, Oxford, UK.

Vilà, M., and P. E. Hulme, editors. 2017. Impact of biological invasions on ecosystem services. Springer International, Cham, Switzerland. https://doi.org/10.1007/978-3-319-45121-3

Voelker, G., and J. E. Light. 2011. Palaeoclimatic events, dispersal and migratory losses along the Afro-European axis as drivers of biogeographic distribution in Sylvia warblers. BMC Evolutionary Biology 11:163. https://doi.org/10.1186/1471-2148-11-163

Vogiatzakis, I. N., G. Pungetti, and A. M. Mannion. 2008. Mediterranean island landscapes: natural and cultural approaches. Springer, Dordrecht, The Netherlands. https://doi. org/10.1007/978-1-4020-5064-0

Wilson, J. R. U., P. García-Díaz, P. Cassey, D. M. Richardson, P. Pyšek, and T. M. Blackburn. 2016. Biological invasions and natural colonisations are different - the need for invasion science. NeoBiota 31:87-98. https://doi.org/10.3897/neobiota.31.9185

Zomeni, M., and I. N. Vogiatzakis. 2014. Roads and roadless areas in Cyprus: implications for the Natura 2000 Network. Journal of Landscape Ecology 7:75-90. https://doi.org/10.2478/jlecol-2014-0010

Editor-in-Chief: Alexander L.Bond Subject Editor: Wayne E.Thogmartin

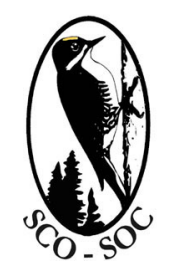

Sponsored by the Society of Canadian Ornithologists and Birds Canada

Parrainée par la Société des ornithologistes du Canada et Oiseaux Canada

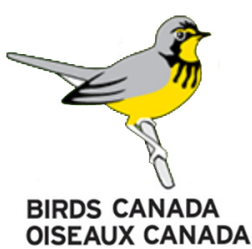




\section{Contents:}

Table A 1.1 Model selection table.

Table A 1.2 Table of relative importance of the fixed effects.

Table A 1.3 Output of DHARMa validation tests.

Table A 1.4 Best fit GLMM output for Sylvia melanothorax.

Table A 1.5 Best fit GLMM output using male individuals of the three Sylvia species as dependent variable. 
Table A 1.1. Model selection table based on corrected Akaike Information Criterion (AICC), in which the best three models with different combinations of predictors are compared for each response variable. Selected models for each response variable are indicated in bold. AICc, delta AICc, AICC weight, log-likelihood (LL) of each model, number of estimated parameters $(\mathrm{K})$ as well as marginal and conditional $\mathrm{R}^{2}$ are presented.

\begin{tabular}{|c|c|c|c|c|c|c|c|}
\hline Model Description & AICc & $\begin{array}{l}\text { Delta } \\
\text { AICc }\end{array}$ & $\begin{array}{c}\text { AIC } \\
\text { weights }\end{array}$ & LL & K & Mar. R2 & Con. R2 \\
\hline $\begin{array}{l}\text { S. melanothorax } \sim \text { season*area } \\
+ \text { habitat } * \text { year }+ \text { Spectacled } \\
\text { warbler + Sardinian warbler + } \\
\text { (1|site) }\end{array}$ & 1054.16 & 0 & 0.49 & -498.06 & 27 & 0.728 & 0.889 \\
\hline $\begin{array}{l}\text { S. melanothorax } \sim \text { season }+ \\
\text { habitat } * \text { year }+ \text { Spectacled } \\
\text { warbler + Sardinian warbler + } \\
\text { (1|site) }\end{array}$ & 1054.91 & 0.75 & 0.34 & -511.84 & 15 & 0.692 & 0.886 \\
\hline $\begin{array}{l}\text { S. melanothorax } \sim \text { season }+ \\
\text { habitat * year }+ \text { Spectacled } \\
\text { warbler + Sardinian warbler + } \\
\text { observer + (1|site })\end{array}$ & 1056.77 & 2.61 & 0.13 & -511.68 & 16 & 0.692 & 0.887 \\
\hline $\begin{array}{l}\text { S. melanocephala season * } \\
\text { area + habitat } * \text { year + Cyprus } \\
\text { warbler + observer + (1| site })\end{array}$ & 917.63 & 0 & 0.54 & -429.79 & 27 & 0.738 & 0.771 \\
\hline $\begin{array}{l}\text { S. melanocephala season * } \\
\text { area + habitat * year + Cyprus } \\
\text { warbler + Spectacled warbler }+ \\
\text { observer + (1|site) }\end{array}$ & 918.35 & 0.71 & 0.38 & -429 & 28 & 0.736 & 0.772 \\
\hline $\begin{array}{l}\text { S. melanocephala season * } \\
\text { area + habitat * year + Cyprus } \\
\text { warbler + Spectacled warbler }+ \\
\text { (1|site) }\end{array}$ & 921.44 & 3.81 & 0.08 & -431.7 & 27 & 0.736 & 0.772 \\
\hline $\begin{array}{l}\text { S. conspicillata } \sim \text { season }+ \\
\text { observer }+(1 \mid \text { site })\end{array}$ & 408.72 & 0 & 0.55 & -199.28 & 8 & 0.003 & 1 \\
\hline $\begin{array}{l}\text { S. conspicillata } \sim \text { season }+ \\
\text { habitat }+ \text { observer }+(1 \mid \text { site })\end{array}$ & 409.56 & 0.85 & 0.36 & -195.55 & 9 & 0.240 & 1 \\
\hline
\end{tabular}


S. conspicillata $\sim$ season + habitat*year + observer + (1|site)

412.6

3.88

$-191.76$

14

0.240

1

Males S. melanothorax

season + habitat * year +

Spectacled warbler + Sardinian warbler + (1| site)

945.3

0

0.44

$-457.03$

15

0.672

0.831

Males S. melanothorax $\sim$ season

* area + habitat * year +

Spectacled warbler + Sardinian

warbler $+(1 \mid$ site $)$

945.76

0.46

$\begin{array}{lll}0.35 & -443.86 & 27\end{array}$

0.710

0.870

Males S. melanothorax $\sim$ season

+ habitat * year + Spectacled

warbler + Sardinian warbler +

Observer + (1| site)

$947.26 \quad 1.96$

0.17

$-456.92$

16

0.671

0.864

Males S. melanocephala

season * area + habitat * year + Cyprus warbler + observer + (1|site)

$853.36-0$

$\begin{array}{lll}0.67 & -397.66 \quad 27\end{array}$

0.707

0.738

Males S. melanocephala season * area + habitat * year + Cyprus warbler + Spectacled warbler + observer + (1|site)

Males S. melanocephala season * area + habitat * year + Cyprus warbler + Spectacled warbler $+(1 \mid$ site $)$

0.03

$-400.82$

27

0.704

0.740

Males S. conspicillata season + habitat + observer + (1| site) 364.95

0

$0.77 \quad-173.25$

9

0.249 1

Males S. conspicillata $\sim$ season + habitat * year + observer + (1|site)

Males S. conspicillata season + habitat * year + Cyprus warbler + Spectacled warbler + observer

$+(1 \mid$ site $)$ 371.16 6.21

0.03 $-168.87$ 
Table A 1.2. The table shows relative importance proportions (Img metrics) for the covariates of the linear models having all individuals of a) Cyprus, b) Sardinian and c) Spectacled warbler and their respective males $(d, e, f)$ as response variables. All response variables have been square root transformed.

a) Cyprus warbler

Img

Fixed effects:

$\begin{array}{ll}\text { Season } & 0.157 \\ \text { Habitat } & 0.604 \\ \text { Year } & 0.040 \\ \text { Spectacled warbler } & 0.115 \\ \text { Sardinian warbler } & 0.038 \\ \text { Habitat } \times \text { year } & 0.043\end{array}$

\section{b) Sardinian warbler}

Fixed effects:

$\begin{array}{ll}\text { Season } & 0.108 \\ \text { Area } & 0.218 \\ \text { Habitat } & 0.492 \\ \text { Year } & 0.018 \\ \text { Cyprus warbler } & 0.014 \\ \text { Observer } & 0.011 \\ \text { Season } \times \text { area } & 0.092 \\ \text { Habitat } \times \text { year } & 0.042\end{array}$

\section{c) Spectacled warbler}

Fixed effects:

$\begin{array}{ll}\text { Season } & 0.027 \\ \text { Habitat } & 0.941 \\ \text { Observer } & 0.030\end{array}$

\section{d) Cyprus warbler males}

\section{Fixed effects:}

$\begin{array}{ll}\text { Season } & 0.164 \\ \text { Habitat } & 0.589 \\ \text { Year } & 0.047 \\ \text { Spectacled warbler } & 0.111 \\ \text { Sardinian warbler } & 0.038 \\ \text { Habitat x year } & 0.048\end{array}$


e) Sardinian warbler males

\section{Fixed effects:}

Season

0.119

Area

0.211

Habitat

0.490

Year

0.018

Cyprus warbler

0.018

Observer

0.015

Season $x$ area

0.085

Habitat $\times$ year

0.040

f) Spectacled warbler males

Fixed effects:

Season $\quad 0.017$

Habitat $\quad 0.956$

Observer $\quad 0.025$ 
Table A 1.3. Output of validation tests performed with DHARMa. The table shows results for onesample Kolmogorov-Smirnov (KS) test, non-parametric dispersion test and bootstrapped outlier test for the models of the three Sylvia species.

\section{Cyprus Warbler:}

KS test

Dispersion test

Outlier test

Sardinian Warbler:

KS test

Dispersion test

Outlier test

Spectacled Warbler:

KS test

Dispersion test

Outlier test

$$
\begin{array}{ll}
\mathrm{D}=0.042 & p=0.453 \\
\text { Disp. }=0.398 & p=0.4 \\
\text { Freq. }=0.002 & p=1
\end{array}
$$$$
\text { Exp. Freq }=0.004
$$

$$
\begin{array}{ll}
\mathrm{D}=0.031 & p=0.824 \\
\text { Disp. }=1.024 & p=0.776 \\
\text { Freq. }=0 & p=0.6
\end{array}
$$$$
\text { Exp. Freq }=0.003
$$

$$
\begin{aligned}
& p=0.065 \\
& p=0.08 \\
& p=1
\end{aligned}
$$

Exp. Freq $=0.007$ 
Table A 1.4. Best fit model for effect of season, area, habitat type, year and other Sylvia species abundance, as well as the interactions of year with habitat and season with area, on the number of adult individuals of Sylvia melanothorax Cyprus, across 402 surveys. Significant results are presented in bold font.

\begin{tabular}{|c|c|c|c|c|}
\hline Random effects: & Variance & Std. dev & & \\
\hline Site code & 0.605 & 0.778 & & \\
\hline Fixed effects: & Estimate & Std. Error & $z$ & $p$ \\
\hline Intercept & 0.609 & 0.545 & 1.117 & 0.263 \\
\hline Breeding & -0.303 & 0.364 & -0.835 & 0.403 \\
\hline Wintering & -0.464 & 0.356 & -1.303 & 0.192 \\
\hline Akrotiri & 0.512 & 0.544 & 0.941 & 0.346 \\
\hline Cape Greko & 0.683 & 0.657 & 1.040 & 0.298 \\
\hline Kouklia & 1.062 & 0.641 & 1.657 & 0.097 \\
\hline Troodos & 0.683 & 0.650 & 1.052 & 0.292 \\
\hline Disturbed mixture & -1.265 & 0.449 & -2.818 & 0.004 \\
\hline Garrigue & -1.369 & 0.450 & -3.037 & 0.002 \\
\hline Pine Forest & -1.161 & 0.442 & -2.626 & 0.008 \\
\hline Saltmarsh & -4.530 & 1.073 & -4.220 & $<0.001$ \\
\hline Year & -0.334 & 0.061 & -5.405 & $<0.001$ \\
\hline Sardinian warbler & -0.117 & 0.056 & -2.076 & 0.037 \\
\hline Spectacled warbler & -0.344 & 0.147 & -2.343 & 0.019 \\
\hline Breeding $\times$ Akrotiri & 0.340 & 0.387 & 0.878 & 0.380 \\
\hline Wintering $\times$ Akrotiri & -0.791 & 0.419 & -1.888 & 0.058 \\
\hline Breeding $\times$ Cape Greko & -0.269 & 0.469 & -0.573 & 0.566 \\
\hline Wintering $\times$ Cape Greko & -0.951 & 0.536 & -1.774 & 0.076 \\
\hline Breeding $\times$ Kouklia & 0.169 & 0.420 & 0.404 & 0.686 \\
\hline Wintering $\times$ Kouklia & -0.474 & 0.440 & -1.075 & 0.282 \\
\hline Breeding $\times$ Troodos & 0.796 & 0.429 & 1.855 & 0.063 \\
\hline Wintering $\times$ Troodos & 0.365 & 0.433 & 0.844 & 0.398 \\
\hline Disturbed mixture $\times$ year & -0.232 & 0.113 & -2.055 & 0.039 \\
\hline Garrigue $\times$ year & 0.275 & 0.118 & 2.332 & 0.019 \\
\hline Pine forest $\times$ year & 0.168 & 0.108 & 1.544 & 0.122 \\
\hline Saltmarsh $\times$ year & 0.972 & 0.936 & 1.038 & 0.299 \\
\hline
\end{tabular}


Table A 1.5. GLMM results of the best supported models (based on lowest AICC score), for the effect of season, area, habitat type, year and other Sylvia species abundance, as well as the interactions of season with area, on the number of male individuals of each Sylvia species that breeds in Cyprus.

Significant results are presented in bold font.

a) Cyprus warbler males

$\begin{array}{lcccc}\text { Random effects: } & \text { Variance } & \text { Std. dev } & & \\ \text { Site code } & 0.675 & 0.821 & & \\ & & & & \\ \text { Fixed effects: } & \text { Estimate } & \text { Std. Error } & \boldsymbol{z} & \boldsymbol{p} \\ \text { Intercept } & 1.042 & 0.325 & 3.205 & \mathbf{0 . 0 0 1} \\ \text { Breeding } & -0.049 & 0.100 & -0.491 & 0.623 \\ \text { Winter } & -0.898 & 0.130 & -6.875 & <0.001 \\ \text { Disturbed mixture } & -1.327 & 0.475 & -2.789 & \mathbf{0 . 0 0 5} \\ \text { Garrigue } & -1.480 & 0.480 & -3.080 & \mathbf{0 . 0 0 2} \\ \text { Pine Forest } & -1.150 & 0.466 & -2.466 & \mathbf{0 . 0 1 3} \\ \text { Saltmarsh } & -4.547 & 1.086 & -4.186 & <0.001 \\ \text { Year } & -0.378 & 0.067 & -5.632 & <0.001 \\ \text { Spectacled warbler } & -0.365 & 0.165 & -2.207 & \mathbf{0 . 0 2 7} \\ \text { Sardinian warbler } & -0.171 & 0.059 & -2.896 & \mathbf{0 . 0 0 3} \\ \text { Disturbed mixture } \times \text { year } & -0.244 & 0.127 & -1.915 & 0.055 \\ \text { Garrigue } \times \text { year } & 0.298 & 0.130 & 2.296 & \mathbf{0 . 0 2 1} \\ \text { Pine forest } \times \text { year } & 0.197 & 0.118 & 1.669 & 0.095 \\ \text { Saltmarsh } \times \text { year } & 1.032 & 0.941 & 1.097 & 0.272\end{array}$

b) Sardinian warbler males

$\begin{array}{lcccc}\text { Random effects: } & \text { Variance } & \text { Std. dev } & & \\ \text { Site code } & 0.093 & 0.305 & & \\ & & & & \\ \text { Fixed effects: } & \text { Estimate } & \text { Std. Error } & \boldsymbol{Z} & \boldsymbol{p} \\ \text { Intercept } & 0.913 & 0.271 & 3.358 & <\mathbf{0 . 0 0 1} \\ \text { Breeding } & -0.801 & 0.300 & -2.667 & \mathbf{0 . 0 0 7} \\ \text { Wintering } & -0.668 & 0.269 & -2.482 & \mathbf{0 . 0 1 3} \\ \text { Akrotiri } & -0.731 & 0.285 & -2.558 & \mathbf{0 . 0 1 0} \\ \text { Cape Greko } & -1.547 & 0.466 & -3.319 & <\mathbf{0 . 0 0 1} \\ \text { Kouklia } & -1.046 & 0.426 & -2.453 & \mathbf{0 . 0 1 4} \\ \text { Troodos } & -2.396 & 0.641 & -3.738 & <\mathbf{0 . 0 0 1} \\ \text { Disturbed mixture } & 0.053 & 0.222 & 0.239 & 0.810 \\ \text { Garrigue } & -1.088 & 0.258 & -4.208 & <\mathbf{0 . 0 0 1} \\ \text { Pine Forest } & -0.815 & 0.242 & -3.369 & \mathbf{0 . 0 0 1} \\ \text { Saltmarsh } & -3.946 & 0.905 & -4.359 & <\mathbf{0 . 0 0 1}\end{array}$




\begin{tabular}{|c|c|c|c|c|}
\hline Year & -0.215 & 0.129 & -1.662 & 0.096 \\
\hline Cyprus warbler & -0.193 & 0.074 & -2.598 & 0.009 \\
\hline Observer 2 & 0.569 & 0.205 & 2.768 & 0.005 \\
\hline Breeding: Akrotiri & 0.346 & 0.377 & 0.918 & 0.358 \\
\hline Wintering: Akrotiri & 1.003 & 0.324 & 3.092 & 0.001 \\
\hline Breeding: Cape Greko & 0.160 & 0.692 & 0.232 & 0.816 \\
\hline Wintering: Cape Greko & 1.901 & 0.497 & 3.824 & $<0.001$ \\
\hline Breeding: Kouklia & 0.898 & 0.521 & 1.721 & 0.085 \\
\hline Wintering: Kouklia & 1.347 & 0.454 & 2.965 & 0.003 \\
\hline Breeding: Troodos & 0.501 & 0.959 & 0.523 & 0.601 \\
\hline Wintering: Troodos & 1.155 & 0.753 & 1.532 & 0.125 \\
\hline Disturbed mixture $\times$ year & 0.197 & 0.127 & 1.551 & 0.120 \\
\hline Garrigue $\times$ year & 0.325 & 0.174 & 1.867 & 0.061 \\
\hline Pine forest $\times$ year & 0.433 & 0.161 & 2.684 & 0.007 \\
\hline Saltmarsh $\times$ year & 1.068 & 0.846 & 1.263 & 0.206 \\
\hline \multicolumn{5}{|c|}{ c) Spectacled warbler males } \\
\hline Random effects: & Variance & Std. dev & & \\
\hline Site code & 16.57 & 4.071 & & \\
\hline Fixed effects: & Estimate & Std. Error & $z$ & $p$ \\
\hline Intercept & -7.275 & 2.292 & -3.174 & 0.001 \\
\hline Breeding & 0.294 & 0.223 & 1.320 & 0.186 \\
\hline Wintering & 0.190 & 0.220 & 0.861 & 0.383 \\
\hline Disturbed mixture & -0.274 & 2.444 & -0.112 & 0.910 \\
\hline Garrigue & 1.200 & 2.401 & 0.500 & 0.617 \\
\hline Pine Forest & -0.595 & 2.495 & -0.239 & 0.811 \\
\hline Saltmarsh & 6.744 & 3.064 & 2.201 & 0.027 \\
\hline Observer 2 & 0.898 & 0.176 & 5.089 & $<0.001$ \\
\hline
\end{tabular}

